\title{
Predictors of Force-driven Religious Conflict
}

\subsection{Introduction}

How do Christian, Muslim and Hindu students' beliefs influence their perception of causes of interreligious conflict? Which beliefs contribute to the perception of coercive force as a means of achieving the economic, political or socio-cultural goals of religious groups? Which beliefs make them attribute interreligious conflicts to force-driven causes? Are there differences in predictors of force-driven religious conflict between Christians, Muslims and Hindus in Tamil Nadu? These are the questions explored in this chapter.

It is structured as follows. First we present a meaning system approach to religion as a theoretical perspective on the relation between religion and conflict. If we suppose that conflicts involve a (re)definition of religious identity and a (renewed) claim to religious authority, we need to map the 'mind-set' of religious people. We regard religious identity as a set of descriptive and prescriptive beliefs shared by members of a religious community (8.2). That still begs the question why some members of religious traditions hold beliefs that support conflict, while others do not. Although religious traditions undoubtedly contain beliefs that may support conflict, this does not imply that all believers concur that religious identification induces conflict, let alone that they legitimize violent activism or even support it. What psychological mechanism explains why some believers attribute interreligious conflict to coercive force used to achieve economic, political or socio-cultural goals, while according to others religion advocates peaceful coexistence? We think that the theory of cognitive dissonance affords insight into the differential influence of religious meaning systems on the perceived relation between religion and conflict at an individual level (8.3). Secondly, we describe our empirical research into the relation between religion and force-driven religious conflict. After formulating the research questions we present the measuring instruments and the research findings (8.4). The chapter ends with a summary and discussion (8.5).

(C) ANTHONY, HERMANS \& STERKENS, 2015 | DOI 10.1163/9789004270862_010

This is an open access chapter distributed under the terms of the Creative Commons AttributionNoncommercial 3.o Unported (CC-BY-NC 3.0) License 


\subsection{A meaning system approach to the relation between religion and conflict}

How can religion be both a source of peace and human fulfilment, and a source of conflict? In this section we outline an approach to religion which clarifies how both these opposing claims can be true. First we explain why we choose a meaning system approach to study the relation between religion and conflict (8.2.1). Next we describe the meaning system approach to religion. This allows us to see religion as a complex, malleable system that is a powerful element in the construction of human identity, both personal and collective (8.2.2). Finally we argue that the same religious meaning system can lead to different stances on changes or transformations in the world in different economic, social and cultural contexts (8.2.3).

\subsubsection{Reasons for Choosing a Meaning System Approach}

Why do we choose a meaning system approach to analyse the relation between religion and conflict? What does this approach offer for such an analysis?

Firstly, the concept of meaning system refers to human beings' belief system, which contains descriptive beliefs about the self, the world and its contingencies and expectations, as well as prescriptive beliefs about goals, actions and feelings (cf. below). A meaning system approach helps us to open up the believer's cognitive structure. Beliefs are seen as convictions with a cognitive aspect, an affective aspect and an action tendency. If one were to restrict religious research to indicators of religious belonging (e.g. religious self-definition or membership) or religious behaviour (e.g. church attendance, prayer, devotional practices or reading holy scriptures), it would reduce religion to a black box which is not understandable in itself. Religion could still play a role in human life, but it would be unclear how it influences other types of convictions and behaviour. The black-box model's lack of explanatory power becomes evident when the same religion seems to influence believers' lives in opposite directions. This applies pre-eminently to the relation between religion and conflict. One and the same religious tradition is able to promote both violent behaviour and peaceful activism. One may not even spot the relation between religion and conflict, because its contrary influences on conflict lead to a lack of correlation in large populations. A meaning system approach is able to differentiate between simplistic statements concerning the relation between religion and conflict. Obviously religious traditions 'in essence' are neither violent nor non-violent. It would be naive to characterize Hinduism as essentially non-violent or Islam as violent (cf. Van der Veer 1994; Fox 2000; Silberman 2005a; 2005b). 
Secondly, a meaning system approach facilitates understanding of the dynamic, process-oriented function of religion in people's lives. The cognitivemotivational approach is an established paradigm in the study of human identity (cf. Emmons 1999; 2005; Singer 2004). Understanding of how a religious meaning system functions can benefit by empirical research and theory building about meaning systems in general. Religious meaning systems differ from each other in their unique motivational power, centredness and comprehensiveness. They are unique in their power to direct the ideas, emotions and actions of human persons and groups. Centredness refers to the ability of religion to centre everything in life on what is considered sacred (God). Finally, comprehensiveness refers to the fact that religion is relatively easily accessible to give significance to a wide variety of experiences and an extensive range of issues. It can give meaning to the deepest, most complex and persistent questions in human life, such as questions of life and death, suffering and happiness, evil and good (cf. Silberman 2005a; Hood et al. 2009, $15 \mathrm{ff}$ ).

Thirdly, a meaning system approach helps us to construct a typology of the relation between religion and conflict. It enables us to classify structurally or functionally equivalent beliefs in different religions for comparative purposes. Equivalence can be established at the level of specific beliefs or attitudes, but also at the level of meaning systems as a whole. The concept of meaning systems makes it possible to construct a typology of religious groups based on their descriptive and prescriptive beliefs about violent or peaceful activism (Van de Vijver 2003; Silberman, Higgins \& Dweck 2005, 767).

Fourthly, a meaning system approach helps to illuminate the complexity of religion (here the existence of contradictory beliefs) and its malleability (here the capacity to change over time). The complexity and malleability of religious traditions mirror their adaptability to the environment. Adaptation happens via two complementary processes: assimilation and accommodation. There is religious assimilation insofar as the environment is interpreted in terms of the schemes and structures of the religious tradition. In assimilation the environment is actively or passively included in the existing belief system. There is accommodation insofar as the religious meaning system changes in keeping with the context. In accommodation the mental structures of the belief system change to be consistent with the reality in which they appear. In the complex relation between religion and conflict something similar happens. On the one hand the religious meaning system contains descriptive and prescriptive beliefs about social reality. In what kind of world do we live? To what extent and by which means do we want to change this world? On the other hand the religious meaning system is influenced by economic, political and cultural circumstances. Which religious convictions should be stressed in the world we 
are living in? How do religious communities deal with the complexity and malleability of their tradition? The following questions are important in this regard: (1) Which changes in the world are desired from a religious perspective? And how can and should religion change in the perspective of its societal context? (2) In what realm should the desired change occur - the economic, political, cultural or religious realm? (3) What are the goals of the desired change? Does it entail adjustment of an existing situation or complete transformation? (4) Which means are effective to accomplish the necessary change? And which means are morally and religiously legitimate with a view to the desired change? A meaning system approach can help us to understand the complex interaction between religion and its environment in terms of transformation of both the religious tradition and the context (cf. Silberman 2005b; Silberman, Higgins \& Dweck 2005, 766ff).

\subsubsection{Religious Identity: A Meaning System Approach}

What do we mean by the religious identity of a person? What does it mean to label somebody Christian, Muslim or Hindu? The concept of identity derives from personality psychology, more specifically its cognitive paradigm that focuses on cognitive-affective processes in identity formation (Singer 2004). Identity refers to people's sense of unity in different situations and throughout their entire lifespan. Individuals filter their experiences through their personal beliefs and theories about themselves, about others, about the world and the relation between self, others and the world. "These beliefs or theories form idiosyncratic meaning systems that allow individuals to give meaning to the world around them and to their experiences, as well as to set goals, plan activities, and order their behavior" (Silberman 2005b, 644). Meaning systems contain descriptive and prescriptive beliefs (Epstein 1990; 1997; Silberman 2005b).

The descriptive beliefs together form a theory of reality. The word 'theory' is misleading insofar as it suggests that people consciously set out to develop theories of reality. The construction of descriptive beliefs rather "happens, automatically and pre-consciously, because it is in the nature of the human mind to make connections between events and ultimately to construct a model of the world" (Epstein 1997, 20). The major descriptive beliefs concern the person's nature (a self-theory, e.g. "I am a believer"); the nature of the world (a world theory, e.g. "God created the world"); and the relation between self and world (e.g. "With God's help I can change the world"). A personal theory of reality is hierarchically organized in a set of schemas. The most basic schemas are referred to as postulates or basic beliefs. "The four basic postulates include the degree to which the world is regarded as benign versus malevolent; the degree to which it is regarded as meaningful (including predictable, control- 
lable, and just); the degree to which others are regarded favourably rather than as a source of threat; and the degree to which the self is regarded as worthy" (Epstein 1990, 165). These postulates are higher-order principles that structure a person's meaning system. If any of them is invalidated, it has a profoundly destabilizing effect on the person's identity. Religious beliefs have a unique quality of grounding the postulates in a transcendent reality. For example, the fact that God created the world gives it a predictable and controllable character.

Prescriptive beliefs are broad generalizations to obtain what one desires and to avoid what one fears. Meaning systems not only contain beliefs about the nature of self and world, but also beliefs about contingencies and expectations regarding the self, the world and the relation between them. Contingencies are about things such as human fate (e.g. "people should be rewarded for good behaviour") and expectations concern things like changing the world through good behaviour (e.g. "good actions can turn the world into a just society"). Prescriptive beliefs orient people to their future existence. What should I do in order to survive? Which emotions are helpful in a certain situation? What (life) goals should I pursue? Goals, actions and emotions are associated with costs and benefits. People adapt their behaviour to their judgment of the costs and benefits. One either gains or loses through specific actions or certain expressions of emotion. Usually people want the benefits to be greater than the costs. Prescriptive beliefs orient people to goals, actions and emotions that are likely to have an outcome in which benefits outweigh costs. ${ }^{1}$ But there are no benefits without costs, and no costs without benefits. Hence there always has to be some trade-off between costs and benefits in specific circumstances (Higgins 2000, 29).

The sociocultural context shapes the meaning that people derive from experiences and how they interpret a situation. Religious persons have different theories of reality, because they are influenced by different social, historical and cultural settings in which they live and by which they are formed. At the same time there are some common principles underlying the construction of meaning systems which explain why they work the way they do. These

1 This cost-benefit approach is different from the classic conflict approach, in which costs and benefits are distributed between different variables (e.g. the id and the superego in a Freudian framework). But it is also different from the limited capacity perspective developed in the 1970s when the cognitive paradigm began to influence psychology (Higgens 2000). The idea was that cognitive failures must underlie failures in human processing and reasoning. The cost-benefit approach does not focus on cognitive failures (as if the mind is not doing what it is supposed to do), but on adaptive mind processes aimed at survival. 
principles are the same for all meaning systems. According to Epstein (1985; $1990 ; 1997)$ meaning systems develop in response to four basic motives. Each motive implies some benefit. The first motive is to optimize one's pleasurepain balance; the second is to assimilate the data of reality into a stable, coherent and reasonably veridical model of the world; the third is about continuity of relatedness with other persons; and the fourth motive is to enhance self-esteem, including autonomy and agency.

A religious meaning system works in much the same way as any other meaning system. It is "similar to other systems in structure, malleability and functioning, yet is unique in centring on what is perceived to be the sacred, and in the comprehensive and special way in which it can serve to fulfil the quest for meaning” (Silberman, Higgins \& Dweck 2005, 764). We clarify the uniqueness of religious meaning systems by giving illustrations of descriptive and prescriptive beliefs in religion. Descriptive beliefs include a theory of the self, a theory of the world, and contingencies and expectations about the relation between the self and the world. Prescriptive beliefs refer to (life) goals, actions and emotions. In other words, religious meaning systems give answers to the following six questions: Who am I? What is the nature of the world? What can I expect from my relatedness to others and to the world? What should I strive for? What should I do? What should I feel?

1. In a religious theory of the self, the self is seen as related to the sacred (Pargament 2007), to an ultimate reality (Tillich 1953) or to a superhuman power with abilities human beings do not have (McCauley \& Lawson 2002). A religious theory of the self includes beliefs about the nature of humankind, such as being sinful or inclined to do good, being focused on one's own pleasures or oriented to the happiness of others. Because of the connection with the sacred, an ultimate reality or superhuman power, religious theories of the self are extremely powerful in orienting people. For religious believers the self finds its fulfilment in God. To find one's true self one needs to be close to God. Losing the (perceived) close relationship with God would plunge believers into despair and anxiety.

2. The core question in a religious theory of the world relates to human flourishing or the way to achieve true happiness (Taylor 2007). When the world is seen as evil, true happiness is unattainable in earthly life. When the world is seen as holy, true happiness is possible provided people live according to rules of life that find their moral ground beyond this world, that is in God. Between these two extremes of evil and holiness mixed positions are possible. One could, for instance, be convinced that evil powers do exist in the world, but that they are subject to God's power. Or one could believe that evil resides in human nature but not in the nature of the world, which is created by God; et 
cetera. When it comes to violent religious activism the concept of evil versus the goodness of the world is a central issue.

3. Religious meaning systems include beliefs concerning the relation between the self and the world. Contingencies and outcome expectations describe the relations between self-theory and world-theory (Epstein 1997, 20). Contingencies may prescribe different rules for treating in-group and outgroup members, or they may teach the circumstances in which one should treat other groups with either compassion or hostility (Silberman 2005b, 646). Outcome expectations concern self-efficacy expectations about world change, the ability of individuals to change themselves and the world around them, and expectations about the means to effect this change. Outcome expectations, then, relate to the perceived legitimacy of violent behaviour to reach goals in the interest of one's own religious group. Some research shows opposition between the wish to change the world and the aspiration to change one's religious tradition. Believers who oppose any change in their tradition are more likely to favour changing the world (and vice versa). "In terms of means to achieve the world change, the more traditionally religious participants endorsed more strongly the mechanism of religious practices and evaluate religious practices as being more instrumental for bringing about world change" (Silberman, Higgins \& Dweck 2005, 768). Religion as a meaning system also includes a sense of self-efficacy by suggesting to believers that they have the power to change both themselves and the world for the better. This power to change the world may be supported to a certain degree by a superhuman power (God), thus giving the expectation of the religious actor incomparably greater efficacy than in other meaning systems (Silberman 2003). In this perspective no power in the world can prevent the transformation that God wants to happen.

4. Religious meaning systems influence forms of self-regulation and may encourage or discourage people to strive for specific life goals (Higgins \& Silberman 1998). Robert Emmons, a personality psychologist studying spiritual goals, refers to goals as strivings which motivate persons to act towards an identifiable end-point that is highly valued (Emmons 1999, 26). Some life goals can never be fully realized despite enormous efforts. Emmons defines these goals as ultimate concerns, because they surpass human powers of realization (Emmons 2005, 736), for example peace, justice, benevolence, forgiveness. The longing for peace or forgiveness never goes away however hard people work to achieve them. "The concept of ultimate concern enables a bridge to be built from issues of ultimacy in the abstract to everyday concerns and goals where issues of ultimacy meet the road" (Emmons 1999, 6). The uniqueness of the religious meaning system is to orient people's lives to goals of ultimate 
concern. In doing so it creates a strong sense of centredness, orienting a person's life to what matters most.

5. On the level of actions religion offers "a set of practices for establishing relationship to a supernatural or transcendent reality, for the sake of obtaining human good or avoiding harm" (Ward 2004, 3). Religious systems stipulate which actions are appropriate and inappropriate. Some actions are seen as prototypically religious or spiritual, such as prayer, meditation and participation in rituals. All actions primarily seek to strengthen the believer's relationship with God. Actions to achieve the human good can include acts of compassion and charity, as well as acts of violence (Silberman 2005). Actions may acquire unique power from a religious meaning system via a variety of processes such as sanctification. By sanctifying an action it is imbued with supreme perceived efficiency and efficacy. The capacity of sanctified actions to contribute to what is considered morally good is put beyond human doubt. Institutionalization plays an important role in establishing religious practices. There is no religion without institutionalization, because religious practices are not natural but institutionally created acts (Hermans 2003). A necessary condition for the creation of institutional acts are the intentions of the participants in religious practices. Certain acts, such as bowing one's head in a particular direction, 'count as' acts of prayer or devotion before God (coram Deo). 'Count as' means the act has the status of linking the believer with a superhuman power. Religious practices are social phenomena. The intentionality which defines something as religious is shared with others. It is possible to perform a religious act privately, but the performance presupposes a religious community which shares the same intentionality. This implies that community members cannot create religious practices on their own authority. The legitimization of a practice as a religious practice depends on the authority of a tradition, which ultimately goes back to the will of God. For example, people are baptized because John the Baptist and Jesus' disciples have taught Christians to do so. Some baptismal gestures and symbols are associated with God's salvific acts such as the journey of the people of Israel through the Red Sea and the creation of heaven and earth. Religious acts are controlled to a greater or lesser extent by religious regimes. A religious regime refers to a system of power relations, which are in some degree formalized and legitimized by theological specialists (Bax 1985).

6. Emotions are influenced by religious meaning systems in different ways (Silberman 2003, 647). In the first place, religions offer people practices to experience a unique, emotionally powerful closeness to God. For example, in rituals the participants look for the act or instrument which conveys the presence of what is seen as God (McCauley \& Lawson 2002). When this close 
relation with an ultimate reality is experienced, it is accompanied by intense emotions, which can be positive (e.g. joy, warmth, pleasure), ambivalent (e.g. being overwhelmed or anxious because of the greatness of God), or negative (e.g. guilt or fear when one does not live up to expectations). Secondly, religious meaning systems may also directly prescribe or prohibit certain (levels of) emotions. For example, participants in a Hindu ritual burning of a deceased person are forbidden to cry, whereas Catholic funeral goers in Latin America express their emotions freely. Thirdly, the beliefs, goals and actions which are part of a religious meaning system influence emotions positively or negatively (Silberman 2005b, 647). For example, people's God concept is important when they have to cope with a stressful event like the loss of a loved one (Pargament 1997).

\subsubsection{Religious Meaning Systems and Religious Conflict: A Dual Relation}

How can a meaning system approach to religion help us to map the dual relation between religions and religious conflicts? Religious meaning systems contain different ideas that may have different, even contradictory effects. While some beliefs in a religious tradition may promote violence, other beliefs in the same religion promote peaceful activism. We give illustrations of this dual relation, following the foregoing structure of a meaning system (8.2.2).

1. Religious beliefs about the nature of the self can focus on human characteristics which encourage either violent or peaceful activism. A human characteristic that facilitates peaceful activism is selflessness (i.e. willingness to serve the needs of others and transcend egoism and self-centredness) through a process of self-effacement before God (Silberman, Higgins \& Dweck 2005, 772). God sets people free from self-centredness and in doing so opens the self to the needs of others. But religion can also focus on beliefs that facilitate violent activism, such as glorification of extreme forms of 'self-sacrifice'. Willingness to give one's life for a cause can be seen as the ultimate demonstration of one's faith in God. To define the self as merely an instrument that should be sacrificed to serve a greater cause can lead to self-effacing violent activism like suicide bombing or unrestrained participation in 'holy' wars.

2. Religious beliefs about the nature of the world can promote both violent and peaceful actions. The conception of the world as good or evil is a key issue in violent activism. Religions provide powerful stories about the future of the world. This future can be an end state in which God corrects all human evil doings in a final drama (including punishment or destruction of individuals who disobeyed the will of God) versus images of a peaceful world recreated in the likeness of the original paradise (i.e. a situation in which everything is good and people live in accordance with God's will) (Silberman, Higgins \& Dweck 
2005). The idea of participating in the final drama of the battle against evil can incite people to violent activism. According to Allport (1966) religions include three beliefs about the relation between self and others that can lead to bigotry: firstly, belief in the absolute and exclusive truth of one's own religion; secondly, the doctrine of election (i.e. the superiority of one's own religious group by virtue of its chosen and privileged status, combined with an evaluation of other groups as 'inferior'); and thirdly the concept of theocracy (i.e. the belief that a monarch rules by divine right and that the church or highest religious authority is a legitimate guide for civil government). Intolerance of others' opinions, identities or lifestyles may encourage violent activism: religious groups who believe that there is no truth and no moral or spiritual value in other religious traditions will see any opposition to their own stand as harmful to others. On the other hand there are beliefs that encourage peaceful religious activism: firstly, the belief that there is truth in different religions; second, the idea that all human beings are brothers and sisters, being children of the same divine creator; and thirdly the belief that humankind has been given the competence to rule society by reason and collective deliberation (i.e. human reason can discover the rules of living together in a just society in accordance with God's will).

3. Religious beliefs regarding contingencies and outcome expectations can both promote violent activism and discourage people from acting violently. A violent act is always morally wrong. All world religions teach that killing is immoral. But all forms of violence, even killing, can be redefined as serving socially worthy or moral purposes. "Religious violence and killing are often redefined through theological reinterpretation as holy wars, as sacred events, or as being fought for God and his honour. These battles are not viewed as violence within the religious meaning system of those who participate in it. On the contrary, they are viewed as religious battles for justice aimed at making a more peaceful and just world" (Silberman, Higgins \& Dweck 2005). The outcome is not wrong in a moral sense because it is the will of God.

4. Religions can even promote life goals by way of violent or peaceful activism. The problem with violent activism is that it contradicts the moral standards of religions with regard to respect for human life, the property of other people, freedom of opinion, et cetera. How, then, do we legitimize actions that are in themselves morally wrong? The power of religions to morally justify any goal or action is the power of sanctification (Silberman, Higgins \& Dweck 2005, 776). The process of religious sanctification is uniquely powerful. If a superhuman power (however conceived) requires a person or group to act violently, this act is beyond any doubt. It is even beyond the moral doubt that it could be wrong because it inflicts physical and emotional harm on fellow human 
beings. So the process of sanctification offers a justification for acts that are in themselves morally wrong. The actors have to dissociate themselves from the immoral quality of their actions. Moral dissociation can involve moral justification, euphemistic labelling and dehumanization (Bandura 2004). Moral justification refers to cognitive redefinition of destructive conduct as serving a socially worthy or moral purpose. Consequently the violence is personally and socially acceptable. Euphemistic labelling refers to the psychological process whereby people act more cruelly when violent actions are given a sanctified label than when they are called aggression. So extremely violent actions are reinterpreted theologically as 'holy wars' or acts in honour of God. Dehumanization refers to the process of stripping individuals or religious groups of their human (i.e. moral) qualities by defining them as subhuman or even satanic or evil. Other people are labelled 'children of Satan', which even obliges a true believer to fight against them.

5. Religions promote actions to strengthen people's relationship with transcendent reality (God). Prescribed religious actions can provoke conflict in different ways (Silberman, Higgins \& Dweck 2005, 75). Some actions might be inherently conflictive, as in the case of religious calls for 'holy wars'. The selfsacrifice of the faithful believer is the ultimate proof of commitment to God and obedience to the religious cause. Other actions can be indirectly conflictive because they threaten the identity of other religious groups. For example, the obligation to evangelize or proselytize has a potential for conflict because other groups may feel their existence is threatened. Although evangelism and proselytism are directed to individuals, religious groups might feel that their way of life is threatened with annihilation. Some religious groups (e.g. Islam) threaten their own members with violence if they change their religious affiliation. An important factor in religious practices is institutionalization (see above). Inherent in this process is control by religious regimes. Religious elites and theological specialists play an important role in controlling religious practices. As long as practices stay within the limits of an orthodox interpretation, changes are permitted. The function of religious regimes is to keep practices within those limits. In other words, religious regimes are a major factor opposing religious transformation. Strong religious regimes (amounting to close monitoring of orthodoxy) are an institutional indication that there is little room for intra-religious transformation. The attitude of religious regimes towards extra-religious transformation is the reverse: by and large they oppose social transformation peacefully, unless it seriously threatens the religious institution itself (Silberman 2005b). If the threat is considered urgent enough, religious institutions provide organizational resources to mobilize believers for violent activism. When that happens highly institutionalized religions with 
powerful religious regimes can contribute greatly to external transformation (i.e. in social realms other than religion). In religions there are also beliefs which counteract institutionalization. One is the belief that the core of religion is the individual's religious experience. This is aptly described in William James's definition of religion as "the feelings, acts and experiences of individual men in their solitude, so far as they apprehend themselves to stand in relation to whatever they may consider the divine" (James 1982/1902). Based on this belief, religious persons will be more inclined to seek experiences with the divine and assign institutionalization a secondary role. When religious people show a preference for religious experiences in their meaning system they are less inclined to promote violent activism, for there is no organizational resource to mobilize believers for violent activism. Summarizing the argument regarding prescriptive beliefs about religious practices, we see a dual relation between religion and violence. A meaning system approach to religion accommodates this dual relation by taking into account the movement towards institutionalization and a focus on personal religious experience within the same religion.

6. Emotions can be connected with violent activism in religion. One of the most powerful negative emotions is anger at the desecration of an object, space or action that is perceived to be sacred (Silberman, Higgins \& Dweck 2005). According to Lazarus anger stems from a demeaning offence against me and mine. "Anger depends heavily on the goal of preserving or enhancing selfor social self-esteem" (Lazarus 1999, 217). The two key appraisal-based meanings at the heart of anger are harm to the self and the assignation of blame. The perception of desecration can evoke intense negative feelings because of the uniqueness and importance of the sacred object or space. It may facilitate violent actions against those who are believed to be the desecrators. The infamous demolition of the disputed Babri mosque at Ayodhya by Hindu fundamentalist groups in December 1992 and its enduring effects on Muslim-Hindu relations in India is an example.

\subsubsection{Consonance and Dissonance in the Religious Meaning System}

Why do some members of a religious tradition hold beliefs that support conflict and violence while others hold beliefs that support solidarity and peace? The fact that a religious conviction is part of a religious tradition says nothing about its prevalence among adherents. Religious socializing agents like religious institutions and schools - even when they have partly differing agendas - try to transmit all religious convictions to new generations. People gradually acquire beliefs when they read holy texts, participate in rituals, listen to preaching, pray, sing or meditate. Religious traditions provide descriptions of their 
perceived reality and prescriptions about how to live. But most members do not subscribe to all beliefs of their religious tradition; and not all individual members hold the same beliefs. Why do some members endorse some beliefs while other members endorse other beliefs? We can rephrase the question in terms of the meaning system of an individual person. By means of what psychological process do people (re)arrange the descriptive and prescriptive beliefs in their personal religious meaning system? As said before, religious meaning systems are complex (i.e. they contain contradictory beliefs) and malleable (i.e. they are able to develop and change over time). The complexity and malleability of religious meaning systems allow individual believers to react differently to their environment. In assimilation the environment is interpreted in their religious schemes and structures. In accommodation the meaning system changes to be in line with the context. People want to have beliefs that are consonant with their behaviour, and vice versa. When they pray they have beliefs regarding the outcome of prayer, which motivate them to pray. If they are violent, they will have beliefs that legitimize their actions. The psychological mechanism for arranging people's beliefs in relation to each other and in relation to their behaviour is called cognitive dissonance reduction. The theory of cognitive dissonance maintains that people are driven by a search for consonance between different beliefs, between their beliefs and their behaviour, and between expectations and reality. Cognitive dissonance theory was formulated more than 50 years ago by Leon Festinger (1957) but has developed further since then (Cooper 2007). In current reformulations management and protection of the self (or identity) play an important role in reducing dissonance. This makes it a very useful theory to understand the psychological dynamics of attributing causes of religious conflict. Earlier we explained the concept of conflict in connection with a (re)definition of selfidentity (7.2). In this section we first summarize the main ideas of the theory of cognitive dissonance, which are helpful to understand the psychological mechanism underlying the (re)arrangement of beliefs within a meaning system. Next, we connect this psychological mechanism with religious conflict as a specific outcome of behaviour in a situation of heightened anxiety and uncertainty (cf. Sidel 2007).

Festinger formulated his theory after studying a small doomsday cult which believed that the earth would be destroyed by a great flood on 21 December 1955. All people would perish except those who believed in the prophecies emanating from the planet Clarion. Festinger and his students expected that the members of the cult would face great cognitive inconsistency on the morning after 21 December if the world as we know it still existed. How did the members of the group restore the internal consistency of their meaning sys- 
tem? How did their attitudes change in a way that was consistent with their experiences after 21 December 1955? The theory of cognitive dissonance is based on the premise that people do not tolerate inconsistency very well. How do we understand this? (Festinger et al. 1956; Festinger 1957; Harmon-Jones \& Mills 1999; Cooper 2007.)

1. In his theory of cognitive dissonance Festinger managed to relate cognitions that until then had been treated independently. Pairs of cognitions can be declared relevant or irrelevant to one another. Once cognitions are considered relevant to one another, they can be either dissonant or consonant. They are consonant if one follows from the other, and dissonant if the opposite follows from each of them.

2. Next, the theory of cognitive dissonance maintains that dissonant cognitions are psychologically uncomfortable. Following his mentor Kurt Lewin's early work on tension systems, Festinger argued that people are motivated to reduce dissonance. Our behaviour is driven by forces which motivate us to act in one way rather than another. The force that Festinger identified was arousal. The theory of cognitive dissonance is based on the premise that dissonant cognitions create an unpleasant state of arousal (i.e. a mental tension state). The drive (or desire) to reduce this tension state is the mechanism that underlies attitudinal change. Put differently, people change their attitudes in order to reduce dissonance. Attitudinal change is motivated by the need to reduce the tension between opposite cognitions. For example, the members of the doomsday cult needed to reduce the tension between the prophecy that the world would be destroyed at a specific moment and the stark fact that it still existed afterwards.

3. The theory of cognitive dissonance posits that the magnitude of dissonance can be expressed in a formula. The greater the dissonance, the greater the arousal. And if there is more arousal, there is a greater need to reduce the tension between opposite cognitions. The formula can be expressed as follows (Cooper 2007, 9):

$$
\text { DISSONANCE MAGNITUDE }=\frac{\text { SUM }(\text { all discrepant cognitions } \mathrm{x} \text { importance })}{\text { SUM }(\text { all consonant cognitions } \mathrm{x} \text { importance })}
$$

"The total magnitude of the tension state of cognitive dissonance is proportional to the discrepant cognitions a person has (the elements above the line in the formula) and inversely proportional to the number of cognitions which are consonant (below the line) each weighted by its importance" (Cooper 2007, 9). For the doomsday cultists named the Seekers the fact that the world still existed after 21 December 1955 was a discrepant cognition. It caused great dis- 
sonance because of its importance for them. The firmness of their belief in the end of the world is illustrated by the fact that some of them had sold their houses and quitted their jobs. Festinger and his colleagues observed that in the days after 21 December the Seekers developed a cognition consonant with their prophecies and sacrifices. This idea was that because of their sacrifices the extra-terrestrials from the planet Clarion decided not to destroy the world. To magnify the importance of this cognition the Seekers publicized it in press releases and interviews. The formula also makes clear how arousal can be decreased by changing attitudes in one of the following ways: (a) changing the importance of discrepant cognitions (numerator, above the line); (b) bolstering consonant cognitions (denominator, below the line); and (c) seeking new cognitions that support discrepant behaviour.

4. According to Festinger dissonance is the result of a tension state arising from a logical (in)consistency between cognitions and behaviour. Currently scholars still accept this motive for attitudinal change, but have expanded it with at least three considerations relating to the (in)consistency between cognitions and actions. Not all scholars agree with these considerations, but we mention them as topics of the debate on dissonance arousal (cf. Cooper 2007, 182).

(a) Dissonance arousal is generated by behaviour, more precisely aversive behaviour. But in order for dissonance to occur individuals have to be responsible for their actions and realize that the consequences are irrevocable. If people are able to absolve themselves of responsibility for an aversive consequence, the motivation to change attitudes disappears. There is no drive to change when responsibility is denied. Responsibility denial is when "they believe they had no choice but to behave as they did and/or the consequence was unforeseeable when they made that choice" (Cooper 2007, 76).

(b) The second consideration concerns the orientation to behaviour, more precisely to aversive behaviour as the cause of dissonance arousal. Dissonance is driven by the perception of unwanted consequences and has little to do with inconsistent cognitions (Cooper 2007, 80). For Festinger it looked as if people were 'hard-wired' to be aroused by inconsistency. However, this does not explain why people are upset by inconsistency. Harmon-Jones (1999) has pointed out that an action orientation combined with the need to survive can explain why we try to get rid of inconsistency. It is not just inconsistency as such, but the effect of inconsistency on our need to adopt an unequivocal stance towards action in the social and physical environment. It is adaptively better to act in a world without ambivalence and conflict. Inconsistent cognitions interfere with our action tendencies and thus create negative emotions. These negative emotions are a sign that we are maladapted to our environment. 
(c) Finally, the role of the self, more specifically the role of self-esteem, needs to be included in the theory of dissonance. The heart of dissonance is not inconsistency as such, but the motivation to maintain a positive self-image of moral adequacy. The so-called self-affirmation theory states: "We want to see ourselves as good, capable, and able to predict outcomes and control outcomes in areas that matter. Awareness of information that threatens this image motivates us to restore it to a state of integrity" (Aronson et al. 1999, 128). The objective of attitudinal change is to restore a sense of global self-worth. Whether the self-affirmation is strong or weak depends on the magnitude of the threat to the self-image.

5. For our research the role of the self in dissonance arousal and attitudinal change is of utmost importance. Self-esteem can play different roles in dissonance arousal. Stone and Cooper (2001) propose three ways of reducing cognitive dissonance in their Self-Standard Model (SSM).

(a) The first way is presented by the classic theory of cognitive dissonance and implies no role for self-identity. Once dissonance is aroused, people turn directly to the task of reducing it. They change their attitudes by changing the importance of discrepant cognitions, by strengthening consonant cognitions or seeking new supportive cognitions. No thoughts concerning the self are involved. The only objective is to justify aversive behaviour.

(b) The second way implies that in the throes of dissonance, positive selfattributes are made accessible to a person. Positive self-attributes are a set of high expectations that functions as a personal standard of judgment in the context of discrepant behaviour. For example, people remind themselves that they are decent humans with high moral standards. How can this affect dissonance? Dissonance is the result of discrepancy between behaviour and personal standards of self-esteem. It does not occur when behaviour is evaluated according to generally shared and distant normative criteria of what is good or bad, foolish or sensible (Stone \& Cooper 2001, 231). Dissonance occurs because the consequences of behaviour are considered unwanted or objectionable by everyone in society or a specific community, most of all by the person responsible for the behaviour. According to self-affirmation theory the standards need to be personal, even idiographic. On the other hand, positive attributes are resources to restore self-esteem. If the cognitions used to reduce discomfort are positive, self-descriptive and related to the discrepant behaviour, dissonance is reduced. For example, I consider myself to be a person who makes good intuitive judgments in interpersonal conflict situations. Based on this positive attribute, I cannot have chosen the wrong behaviour in this situation (although others may say so!). This positive self-descriptive cognition reduces the experience of discomfort, hence dissonance (cf. Cooper 2007, 110). 
(c) The third way implies a situation in which positive self-attributes are made accessible to a person but are not considered relevant to the behaviour.

In a meaning system approach people will hold beliefs that are consonant with each other. Based on the theory of cognitive dissonance, we can expect descriptive and prescriptive beliefs in a religious meaning system to display cognitive consistency. In Festinger's original theory (1957) the realm of consonance/dissonance was restricted to comparison of the consistency or inconsistency of cognitions, but in later theories the self and motivated reasoning also played a role in cognitive dissonance (Cooper 2007). Maintaining cognitive consistency is a way to protect a positive self-image. A person will try to minimize dissonance between different beliefs in the meaning system. Or, put differently, a person will hold beliefs that give rise to maximum consonance.

Earlier we defined the context of religious conflicts as a heightened state of uncertainty and anxiety. According to Sidel (2007) people in this situation seek to (re)articulate the authority claims of their religion and to (re)define their identity, because authority claims and strong identity definitions offer solid ground to withstand uncertainty and anxiety. When people feel threatened and uncertain they need a firm basis in order to survive. This is precisely what religion offers: it has exceptional power to contribute to personal or collective identity and it claims great authority. If something is decreed by God, there can be no doubt about its righteousness and accuracy. Religious conflicts are also considered to be connected with societal transformation. Force-driven religious conflict is seen as violent activism to bring about world change or transformation. For example, if the political equation changes because of conversion of Hindus to Islam or Christianity, this situation needs to be transformed by means of conflict. Societal transformation refers to an urgent drive to change a given imperfect state into a desired state. It includes continuity and discontinuity between the imperfect state and the improved situation. Cognitive consistency is important for people to maintain a stable meaning system. "As threat to the stability of their conceptual system mounts, people experience increasing anxiety and a tendency for their conceptual system to become disorganized. When disorganization is imminent, the anxiety becomes overwhelming, and people will do whatever they can to reduce its intensity and prevent disorganization" (Epstein 1990, 172). 


\subsection{Empirical Research}

\subsubsection{Research Question}

The following research question was formulated in light of the foregoing theoretical perspective: to what extent can agreement with force-driven religious conflict by Christian, Muslim and Hindu students in Tamil Nadu be explained by descriptive beliefs about the relation between self and others and prescriptive beliefs about religious action, while controlling for the socio-cultural, socio-economic and socio-religious background of the students?

In a meaning system approach the attribution of religious conflict is understood as an outcome expectation. Outcome expectations are beliefs involving self-efficacy expectations about world change, the ability of individuals and groups to change the world around them and expectations about the means to effect this change. The outcome expectation in our research is formulated as " $x$ encourages $y$ ", in which ' $y$ ' is defined as interreligious conflict and ' $x$ ' refers to either socio-economic, political, ethnic-cultural or religious force-driven causes (cf. 7.2). If a religious group overtly or tacitly approves violence as a means of socio-economic change, this can encourage interreligious conflict. Changes in the political equation in Indian society can lead to conflict between religious groups. Linking ethnic or national identity to a particular religion is conducive to religious conflict. And superiority feelings of specific groups can foment religious conflict. We speak about force-driven religious conflict because of the use of coercive force as a means of effecting societal change. Adherents of other religious traditions, individually or collectively, are forced to accept an unwanted change or the rejection of desired change (' $x$ '). The focus of our research is on force-driven religious conflict, which can be seen as a belief about outcome expectations. Force-driven religious conflict will be consonant with other beliefs in the meaning system, both prescriptive beliefs (i.e. beliefs about contingencies and expectations about the self, the world and the relation between them) and descriptive beliefs (i.e. beliefs about the nature of the self and the world). We included several prescriptive beliefs and descriptive beliefs which we expected to affect the extent to which people attribute interreligious conflict to force-driven causes. The prescriptive beliefs are institutional religious practice and vertical mysticism; the descriptive beliefs concern the models of interpreting religious plurality and religiocentrism.

The first type of prescriptive belief included in our research is involvement in institutional religious practice (cf. chapter 3 ). The reason for including it is the authority claimed by religious institutions. Religious institutions tend to control believers' practices as a means of opposing change in their tradition. Strong motivation to learn more about the beliefs and doctrines of one's 
religious tradition; evaluating reading sacred scriptures as important; keen interest in the moral values of one's religion; and considering participation in religious worship important are all seen as indicators of the respondent's willingness to comply with the authority of religious institutions. Force-driven religious conflict implies societal transformation. A demand for external change coincides with internal opposition to change. The reason behind both processes is the same, namely insistence on the authority of my religion. We therefore expect students who agree with institutional religious practice to agree with force-driven religious conflict (hypothesis 1 ).

A second prescriptive belief which can influence agreement with forcedriven religious conflict is vertical mysticism (cf. chapter 4). Religions can favour personal mystical experiences of union with a higher reality. Mystical experiences are not institutionally controlled. They can happen to believers of all religious traditions, independently of religious institutions or theologically trained authorities. Nevertheless vertical mysticism relates positively to perceived positive influence of friends, the religious community, teachers/professors and the media on personal religiosity. In other words: revelatory and ineffable experiences of union with a greater reality correlate with a perceived positive influence of most agents of religious socialization. Mysticism also relates positively to intrinsic religiosity (Hood \& Morris 1990; Campbell et al. 2010) and religious or spiritual practice (Hood et al. 2009, 362ff). Overall, then, it seems likely that vertical mysticism relates negatively to the attribution of interreligious conflict to force-driven causes. People who have had vertical mystic experiences are unlikely to see coercive power as a means of achieving economic, political or socio-cultural goals as the core of interreligious conflict. Hence students who agree with vertical mysticism will agree less with forcedriven religious conflict (hypothesis 2).

The first type of descriptive belief concerns the question of truth in a context of religious plurality. We distinguish between three models of interpreting religious plurality: monism, commonality pluralism and differential pluralism (cf. chapter 5). Monism refers to belief in the absolute validity of one's own religion. People who think that other religions do not contain any truth are likely to denigrate the ideas and convictions of other traditions. We consider it likely that agreement with monism induces a belief that coercive force, including perceived radicalism of other religious groups, is at the root of interreligious conflict. Commonality pluralism stresses underlying - sometimes amorphous - universal aspects shared by all religions in pluralistic encounter. Differential pluralism sees differences between religions as avenues for growth and development. We expect believers who agree with either form of pluralism to show less agreement with force-driven religious conflict because of their open 
attitude towards other religious traditions. In short: students who agree with monism will agree more with force-driven religious conflict (hypothesis 3); students who agree with commonality pluralism will agree less with force-driven religious conflict (hypothesis 4); and students who agree with differential pluralism will agree less with force-driven religious conflict (hypothesis 5).

The second type of descriptive belief concerns the relation between self and other in religiocentrism. Religiocentrism includes a combination of positive in-group attitudes and negative out-group attitudes (cf. chapter 6). Positive ingroup attitudes mean that positive characteristics like faithfulness, goodness or the ability to speak meaningfully about God are associated with one's own religious group. Negative out-group attitudes strip other believers of their moral qualities and put them in a bad light (e.g. by declaring them intolerant or sanctimonious). What is the relation between religiocentrism and (the attribution of) interreligious conflict? At first sight it seems likely that religiocentrism relates positively to conflictive relations between religious groups. Inasmuch as in-group superiority and out-group inferiority are part of religiocentrism, they offer motives to treat others a-morally. Consequently respondents who display relatively high levels of religiocentrism are likely to attribute interreligious conflicts to force-driven causes. Those who consider their own tradition superior to other traditions when comparing group characteristics will not hesitate to use coercive force to achieve the goals of the religious in-group. In that case it is not difficult to regard coercive force as an important factor in interreligious conflict. But positive in-group attitudes do not necessarily imply feelings of superiority. Group characteristics have to be compared to speak of 'superiority', and comparison is only one aspect of social identity construction, along with categorization and identification (cf. 6.2). It might well be that positive in-group attitudes are indicators of religious belonging and commitment to one's own religious tradition, without implying superiority or exclusive truth claims. This means that the relation between positive in-group attitudes and force-driven religious conflict depends on other mediators and moderators. Only when one's own group is seen as superior to other groups, and only when positive in-group attitudes are combined with or even take the form of absolute truth claims will positive in-group attitudes contribute to the attribution of interreligious conflict to force-driven causes. But insofar as positive in-group attitudes are merely an indicator of religious commitment to one's own group they will reduce agreement with force-driven religious conflict. How difficult is it for the religiously committed to see religiosity as intertwined with or even responsible for conflict? It remains to be seen what we find in our Tamil Nadu student population. However, some previous research in Asian contexts helps us to form tentative expectations. Camacho (2014) does not find any influence 
of positive in-group attitudes on support of violence in the Philippines, although Subagya (2015) established a very small correlation in Indonesia. Hadiwitanto (2015), on the other hand, establishes a clear (positive!) correlation between positive in-group attitudes among both Christians and Muslims in Indonesia and forms of generalized trust in others. In other words: in the latter case it is likely that religious commitment manifested as positive in-group attitudes contributes to out-group trust.

Expectations regarding the potential influence of negative out-group attitudes on force-driven conflict are more straightforward. Negative out-group attitudes intrinsically entail negative evaluation of other groups, so one would reasonably expect them to induce agreement with force-driven religious conflict. The complexity of the potential effects of religiocentrism is mirrored in its classic bi-factorial structure: positive in-group attitudes and negative outgroup attitudes clearly correlate, but not strongly enough to warrant combining them in a single, empirically validated concept. Summarizing the relation between religiocentrism and religious conflict we can formulate two expectations. Since our measurement of positive in-group attitudes does not entail attitudes of superiority but rather points to religious commitment to one's own group, we expect students who agree with positive in-group attitudes to agree less with force-driven religious conflict (hypothesis 6). On the other hand, students who agree with negative out-group attitudes will agree more strongly with force-driven religious conflict (hypothesis 7 ).

\subsubsection{Measuring Instruments}

The measuring instruments were described in some detail in chapters 3 to 7 . Here we merely mention them briefly.

The measurement of force-driven religious conflict comprises items that measure the extent to which respondents agree that coercive power is at the root of interreligious conflict. The coercive force can be part of religious radicalism, or be used to achieve the economic, political or socio-cultural goals of religious groups (cf. chapter 7). Institutional religious practice has doctrinal, ethical and ritual dimensions. Doctrinal learning practices are measured by asking whether respondents are interested in learning more about the beliefs and doctrines of their own religion. The ethical dimension refers to strengthening the moral values upheld by the religion, and the ritual dimension refers to participation in ritual activities performed by theologically trained leaders of the relevant religious tradition (cf. chapter 3). Vertical mysticism measures union with a higher reality. It combines the idea of a loss of self with the noetic quality (i.e. need for special knowledge or insight) and ineffability (i.e. difficulty of articulating the meaning) of a mystical experience (cf. chapter 4). 
With regard to models of interpreting religious plurality, we used three measurements: monism; commonality pluralism; and differential pluralism (cf. chapter 5). Religiocentrism is the combination of positive in-group attitudes and negative out-group attitudes. Positive in-group attitudes are measured in the same way for all religious groups. Measurement of negative out-group attitudes differs for each group. Negative out-group attitudes are seen as groupspecific, reflecting a religious group's specific negative stereotypes of another group (cf. chapter 6).

\subsubsection{Conceptual Model and Design of Data Analysis}

To analyse the predictors of the force-driven religious conflict we used Structural Equation Modelling (SEM technique). SEM requires not only explicit theoretical expectations about the relation between the variables, but also a sparse model (cf. 1.7 in chapter 1 for a more detailed description).

(a) In the first place we are interested in the influence of prescriptive and descriptive beliefs on the attribution of force-driven causes of interreligious conflict. We tested for the influence of these beliefs insofar as they correlated significantly with force-driven religious conflict in at least one of the religious groups (Christian, Muslim or Hindu).

(b) We also tested for the direct influence of personal characteristics on force-driven religious conflict and their indirect influence via prescriptive and descriptive beliefs. To limit the model we only did so if the personal characteristic showed a minimum association of .20 with force-driven religious conflict (for direct influence) or the relevant belief (for indirect influence) in at least one religious group. We did not require this level of association of all three groups, since there can be different predictors in each religious group. Based on this criterion we removed the following variables from our model: age, mother tongue, caste, mother's occupation, father's occupation, and years attending schools affiliated with one's own religion. Using the same criterion we also had to remove all socio-religious characteristics associated with socializing agents in the religious domain. Because respondents with more than one missing value were excluded from the analysis, there were 805 Christian students (out of a total of 869 Christian respondents), 724 Hindu students (out of 789 respondents), and 217 Muslims students (out of 255 respondents).

The resultant model is presented in Table 8.1. Agreement with force-driven religious conflict is the dependent variable. All descriptive and prescriptive beliefs may influence the level of agreement with force-driven religious conflict. These potential influences are depicted by an arrow from the beliefs box to the dependent variable. There are also five student characteristics included in the model: gender, urbanization, field of specialization, and mother's and father's educational level. In this model the student characteristics can influence 


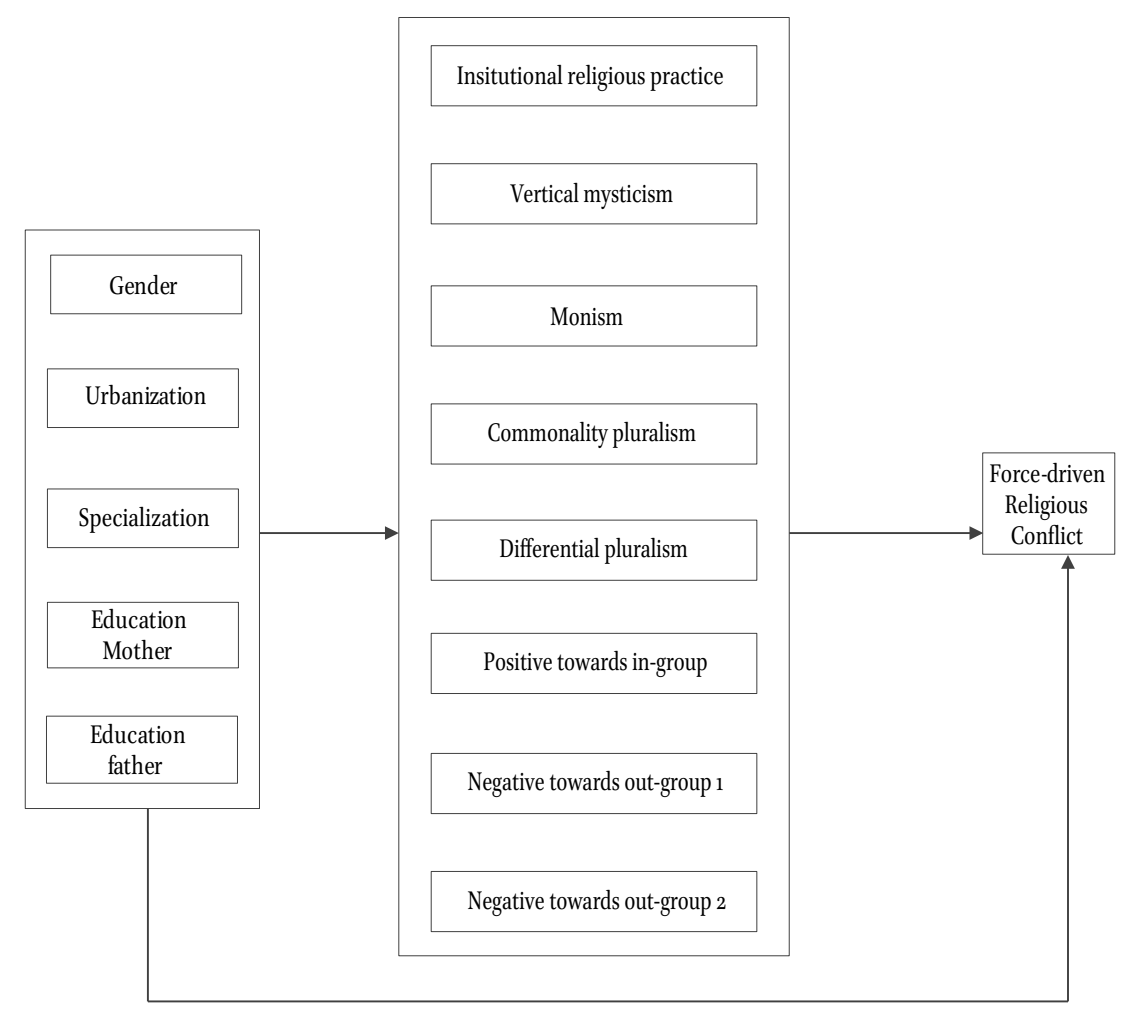

FIGURE 8.1 Structural model to analyse the influence of beliefs and students' characteristics on agreement with force-driven religious conflict.

agreement with force-driven religious conflict directly as well as indirectly by way of beliefs. Actually there should be an arrow from each student characteristic to each belief, and from each student characteristic to force-driven religious conflict. But for the sake of simplicity we replaced this labyrinth of lines with a single arrow from the box of student characteristics to beliefs and one arrow from student characteristics to force-driven religious conflict.

\subsubsection{Empirical Results}

We first present the results for Christian students, next for Muslim students and finally for Hindu students.

Which beliefs of Christian students predict their agreement with force-driven religious conflict, while controlling for their socio-cultural, socio-economic and socio-religious background? The results of our SEM analysis are presented in Figure 8.2. The model is not rejected, that is it can be accepted as an explanation of the level of agreement with force-driven religious conflict among Christian students. 


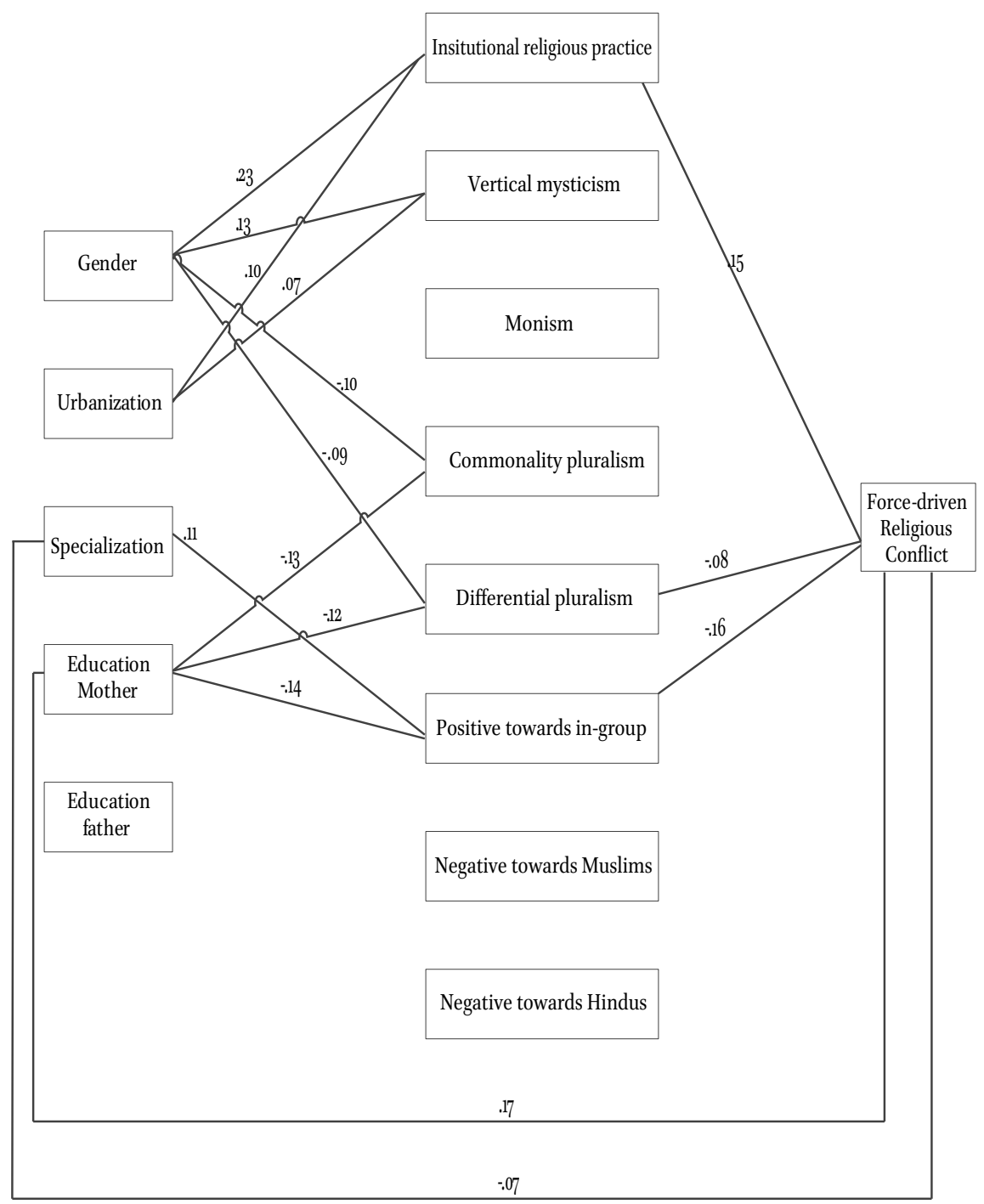

FIGURE 8.2 Structural model of the influence of beliefs and personal characteristics on force-driven religious conflict among Christian students (beta coefficients). ${ }^{2}$

We start our description of the results with the intermediate variables, and then describe the influence of the independent variables.

2 The model is not rejected: $\chi^{2}=2.38$; d.f. $=3 ; \mathrm{p}=.50$; $\mathrm{rmsea}=.00$. The unexplained variance or error-variance of force-driven conflict is .89. The explained variance $\left(\mathrm{R}^{2}\right)$ of the model is .11. 
Christian students agree more with force-driven religious conflict if they are closely involved in institutional religious practices $(\beta .15)$ and show less agreement with differential pluralism ( $\beta-.08)$. These findings confirm the expectations in hypotheses 1 and 5 respectively. Furthermore, low agreement with positive in-group attitudes predicts greater agreement with force-driven religious conflict ( $\beta-.16)$, a finding we did propose as a possible result in hypothesis 6 . We will discuss these findings in the next section.

Two personal characteristics directly influence agreement with force-driven religious conflict: higher level of education of the mother $(\beta .17$ - the highest beta coefficient in our model) and studying the arts or social sciences $(\beta-.07)$. The latter means that students of the arts and social sciences show more agreement with force-driven religious conflict than science students. Seemingly it is easier for students of disciplines in which religion is likely to be studied (arts and social sciences) to recognize the force-driven causes of interreligious conflict than for students of disciplines in which religion is not studied (natural and life sciences).

Other personal characteristics have an indirect influence on force-driven religious conflict via beliefs (gender, urbanization and again field of specialization and mother's educational level). Female students $(\beta .23)$ and those who have been living in urbanized areas $(\beta .10)$ participate more in institutional religious practice than men and those who have lived in the countryside, but Christian men ( $\beta$-.o9) agree more with differential pluralism than women. A relatively low educational level of the mother $(\beta-.12)$ is associated with greater agreement with differential pluralism. Among Christian students positive ingroup attitudes are prevalent among science students $(\beta$.11) and those whose mother's educational level is relatively low $(\beta-.14)$. Of all personal characteristics, mother's educational level shows the strongest link with force-driven religious conflict, both directly and indirectly. Gender, urbanization and field of specialization are also relevant to agreement with force-driven religious conflict. We will reflect on these empirical results under findings and discussion (8.4).

Which beliefs of Muslim students predict force-driven religious conflict while controlling for socio-cultural, socio-economic and socio-religious personal characteristics (cf. Table 8.3)? Muslim students agree more with forcedriven religious conflict if they show relatively high levels of participation in institutional religious practices $(\beta .13)$ and agree with commonality pluralism $(\beta .18)$. The first result confirms our expectation (hypothesis 1 ), but the second result contradicts our expectation in hypothesis 4 . We will reflect on this anomaly in the discussion (8.4). 


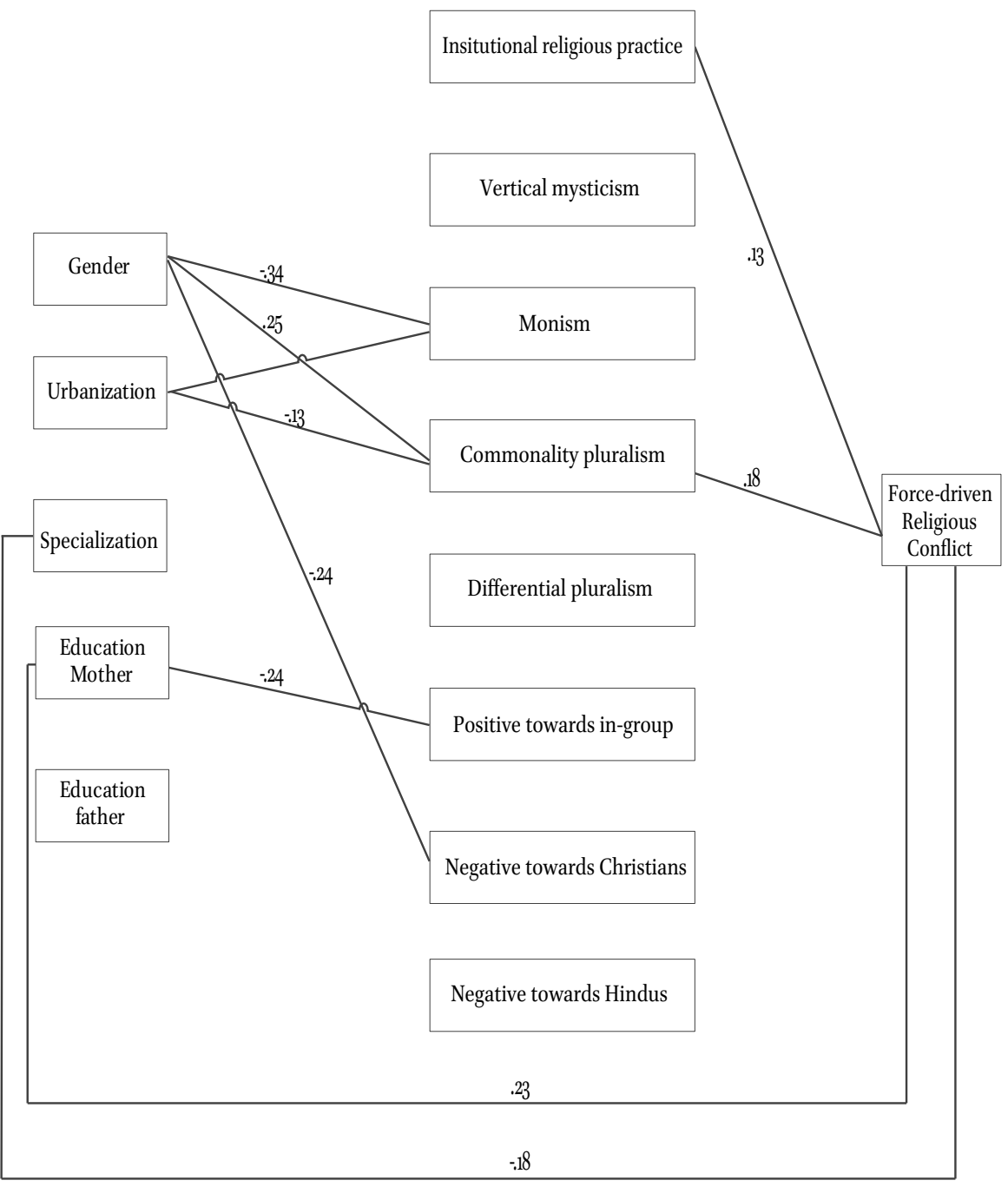

FIGURE 8.3 Structural model of the influence of beliefs and personal characteristics on force-driven religious conflict among Muslim students (beta coefficients). ${ }^{3}$

Two personal characteristics directly predict agreement with force-driven religious conflict among Muslim students: a higher level of education of the mother $(\beta .23)$ and studying the arts or social sciences $(\beta-.18)$. These are identical with the results for our Christian students.

3 The model is not rejected: $\chi^{2}=4.91$; d.f. $=3 ; \mathrm{p}=.18$; rmsea $=.05$. The unexplained variance or error-variance of force-driven conflict is .83 . The explained variance $\left(\mathrm{R}^{2}\right)$ of the model is .17. 


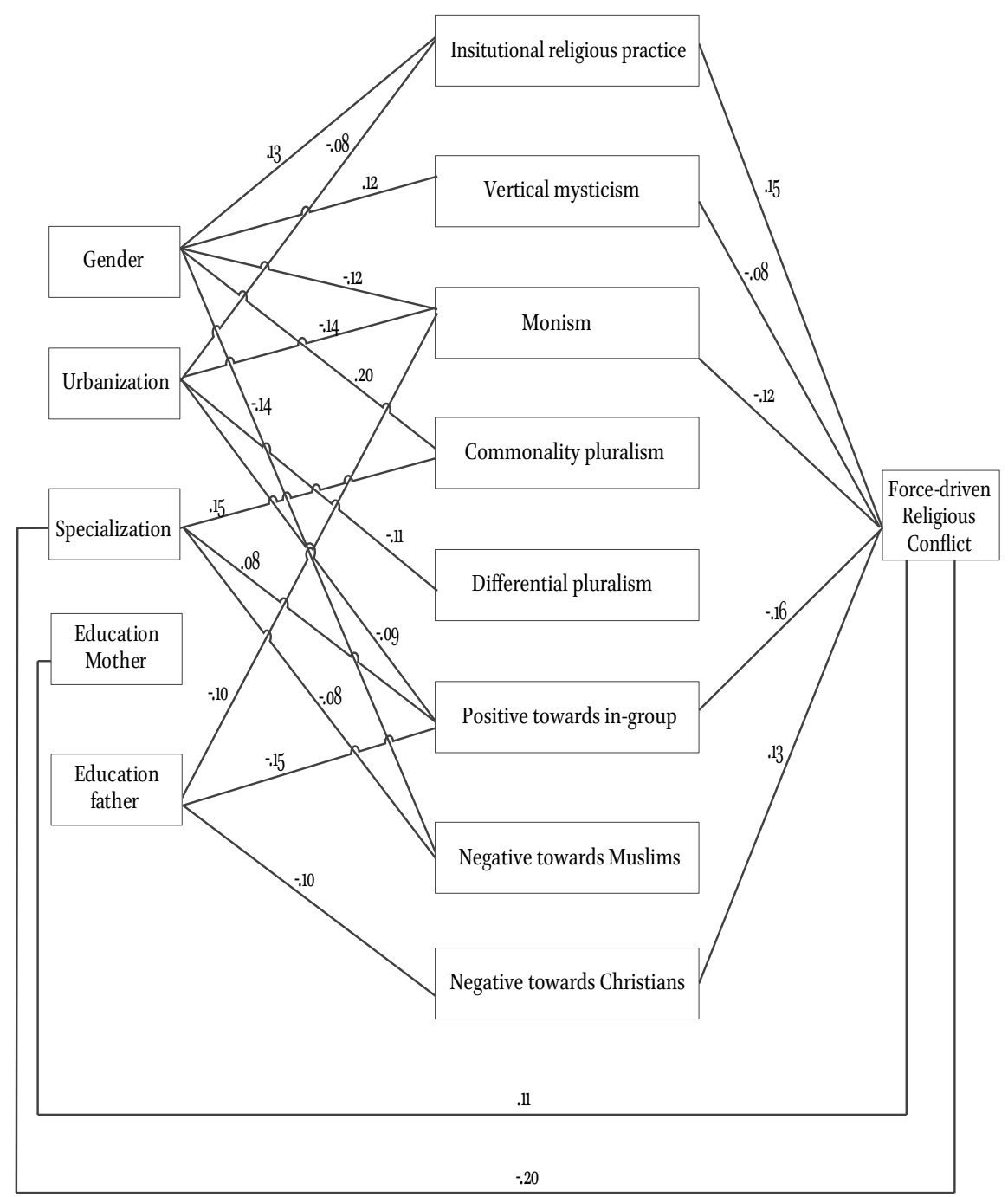

FIGURE 8.4 Structural model of the influence of beliefs and personal characteristics on force-driven religious conflict among Hindu students (beta coefficients). ${ }^{4}$

Two personal characteristics indirectly influence force-driven religious conflict through commonality pluralism: gender and urbanization. Muslim female students agree more with commonality pluralism than men $(\beta .25)$ and students who used to live in less urbanized areas agree more with commonality pluralism as well $(\beta-.13)$.

4 The model is not rejected: $\chi^{2}=2.73 ;$ d.f. $=3 ; \mathrm{p}=.44 ; \mathrm{rmsea}=.00$. The unexplained variance or error-variance of force-driven conflict is .85 . The explained variance $\left(\mathrm{R}^{2}\right)$ of the model is .15 . 
Finally: which beliefs predict force-driven religious conflict among Hindu students while controlling for socio-cultural, socio-economic and socio-religious personal characteristics (cf. Table 8.4)? Two prescriptive beliefs are linked with force-driven conflict: greater involvement in institutional religious practices $(\beta .15)$ and less vertical mysticism ( $\beta$-.08). These findings confirm our first and second hypotheses. Three descriptive beliefs predict agreement with force-driven conflict: lower levels of agreement with monism ( $\beta-.12)$, contradicting our hypothesis 3 ; lower levels of positive in-group attitudes $(\beta-.16)$; and higher levels of negative (out-group) attitudes towards Christians ( $\beta$.13). This means that religiocentrism both reduces and induces attribution of interreligious conflicts to force-driven causes. Positive in-group attitudes reduce agreement with force-driven religious conflict, while negative out-group attitudes - at least negative attitudes towards Christians among Hindus - induce agreement with force-driven religious conflict. We will discuss these remarkable results in section 8.4.

Two personal characteristics directly predict greater agreement with forcedriven religious conflict among our Hindu respondents: a relatively high educational level of the mother $(\beta .11)$ and studying arts or social sciences $(\beta-.20)$. These are identical with the results found among Christian and Muslim respondents.

All personal characteristics are indirectly linked with force-driven religious conflict. Female Hindu students are more involved in institutional religious practices than men ( $\beta .13)$, as are students who have lived in rural areas $(\beta-.08)$. Women have more mystical experiences than men ( $\beta$.12). Hindu men $(\beta-.12)$, Hindus who lived in less urbanized areas $(\beta-.14)$ and whose fathers have relatively low educational levels $(\beta-.10)$ show greater agreement with monism. Agreement with positive in-group attitudes is linked with living in less urbanized areas ( $\beta$-.o9), lower levels of father's education $(\beta-.15)$ and studying natural sciences $(\beta$.08). Agreement with negative out-group attitudes towards Christians is linked with a lower educational level of the father $(\beta-.10)$. Note that the indirect effect of father's educational level on force-driven religious conflict goes in the same direction as the direct effect of mother's educational level. Generally higher parental educational levels relates to greater agreement with force-driven religious conflict.

\subsection{Findings and Discussion}

To what extent can the attribution of interreligious conflict to force-driven causes be explained by descriptive and prescriptive beliefs among Christian, 
Muslim and Hindu students in Tamil Nadu, while controlling for students' socio-cultural, socio-economic and socio-religious characteristics? In this section we first summarize the direct predictors of force-driven religious conflict for each religious group and then explicitly refer to the hypotheses formulated earlier concerning each belief in our research model (8.4.1). In the discussion we reflect on some remarkable findings from the perspective of our theoretical framework, namely the religious meaning system approach and the theory of cognitive dissonance. More specifically, we discuss the positive influence of monism and commonality pluralism on agreement with force-driven religious conflict, the differential influence of religiocentrism, and the direct influence of mother's educational level on agreement with force-driven religious conflict (8.4.2).

\subsubsection{Findings}

We can summarize our research findings for each of the religious groups as follows (cf. Table 8.1).

Among Christian students institutional religious practice increases attribution of interreligious conflicts to force-driven causes, while differential pluralism and positive in-group attitudes reduce it. As far as personal characteristics are concerned, a more highly educated mother and studying arts or social sciences (as opposed to natural sciences) predict greater agreement with forcedriven religious conflict.

Among Muslim students institutional religious practice and commonality pluralism contribute to the attribution of interreligious conflicts to force-driven causes. Secondly, a more highly educated mother and studying arts or social sciences predict greater agreement with force-driven religious conflict.

Among Hindu students five beliefs are found to influence attitudes towards force-driven religious conflict. Institutional religious practice increases attribution of interreligious conflicts to force-driven causes. Vertical mysticism, monism and positive in-group attitudes reduce agreement with force-driven interreligious conflict, whereas negative attitudes towards Christians contribute to it. The findings concerning the personal characteristics are identical with those among Christian and Muslim respondents: higher educational level of the mother and studying art or social sciences increase agreement with force-driven conflict.

What do these research findings imply for the hypotheses formulated for each belief (cf. 8.3.1)? Did the hypotheses pass the test of falsification? And are the beliefs included in our model generally able to predict agreement with force-driven religious conflict? 
TABLE 8.1 Direct predictors of force-driven religious conflict among Christian, Muslim and Hindu students with reference to hypotheses.

\begin{tabular}{lccc}
\hline & Christians & Muslims & Hindus \\
\hline Prescriptive beliefs & & & \\
H 1: Institutional religious practice & + & + & - \\
H 2: Vertical mysticism & & & $-*$ \\
Descriptive beliefs & & $+*$ & - \\
H 3: Monism & - & + \\
H 4: Commonality pluralism & - & \\
H 5: Differential pluralism & & & + \\
H 6: Positive in-group attitudes & & + \\
H 7: Negative out-group attitudes & & + & + \\
Personal characteristics & + & + & + \\
Educational level mother & + & + \\
Art \& social sciences & & & + \\
\end{tabular}

Legenda: '+' indicates a positive effect; '-' indicates a negative effect; ${ }^{\text {(*) }}$ indicates a finding that contradicts the earlier formulated hypothesis.

The first hypothesis concerns the prescriptive belief about institutional religious practice. Our hypothesis is corroborated by the results from all three religious groups: interreligious conflicts are (more widely) attributed to force-driven causes when students display higher levels of institutional religious practice.

The second hypothesis concerns the negative relation between vertical mysticism as a prescriptive belief and force-driven religious conflict. This hypothesis is corroborated by our findings. More specifically, Hindu students who report less experience of mystical union with an ultimate reality agree more strongly with force-driven religious conflict.

In a third hypothesis we argued that greater agreement with monism would be associated with greater attribution of interreligious conflict to force-driven causes. This hypothesis was falsified. Hindu students who disagree relatively strongly with the belief that there is absolute truth in their tradition are more inclined to attribute religious conflict to force-driven causes. We will come back to this surprising result in the discussion. Although our hypothesis is falsified, this result justifies including monism as a relevant belief in the religious meaning system when it comes to religious conflict. 
Our fourth hypothesis concerning commonality pluralism is also falsified. Contrary to what we expected, we found that Muslim students who agree with commonality pluralism show greater agreement with force-driven religious conflict.

The fifth hypothesis regarding differential pluralism is corroborated in our group of Christian respondents. Christian students who disagree with differential pluralism agree more strongly with force-driven religious conflict.

Our sixth hypothesis expected positive in-group attitudes to correlate negatively with force-driven religious conflict, in that relatively more positive ingroup attitudes reduce the attribution of interreligious conflict to force-driven causes and less positive in-group attitudes increase it. This hypothesis is corroborated among our Christian and Hindu research groups. Seemingly believers who are less involved with their religious in-group agree more with force-driven religious conflict.

The seventh hypothesis concerns negative out-group attitudes. We proposed that negative out-group attitudes would increase the likelihood of attributing interreligious conflict to force-driven causes. This hypothesis, too, is confirmed for Hindu students with regard to their negative out-group attitudes towards Christians, but not with regard to their negative attitudes towards Muslims, neither for Christian and Muslim respondents' negative out-group attitudes.

\subsubsection{Discussion}

We highlight some of our remarkable findings, starting with the negative influence of the descriptive beliefs of monism and commonality pluralism on force-driven religious conflict, followed by the differential effect of religiocentrism on the attribution of interreligious conflicts, and ending with the direct influence of the mother's educational level on greater agreement with forcedriven religious conflict.

\section{Monism}

A first anomalous result - at least in terms of our hypotheses - is that the more Hindu students agree with the idea that their religion holds absolute truth, the less they agree with force-driven religious conflict. How do we explain that disagreement with religious monism predicts greater attribution of interreligious conflict to force-driven causes?

The explanation could lie in the attitudinal difference with regard to truth claims between the monotheistic religions (Christianity and Islam) on the one hand, and 'polytheistic' Hinduism on the other. Christianity and Islam are 'religions of the book', which connect religious truth to some degree with what 
they consider to be a unique revelation in the Bible or Qur'an. This is very different from the major Hindu movements. By and large Hinduism has always been good at integrating new ideas and practices, including those of other religious traditions. The major movements in Hinduism all accept different ways to liberation (moksha), and worship of different gods. This distinction between Hinduism and the religions of the book is reflected in the level of agreement with monism. On the whole monism finds little support even among Christian and Islamic students in Tamil Nadu, but it is rejected even more emphatically by Hindu students. As noted already, this difference between Christians and Muslims on the one hand and Hindus on the other is both relevant and statistically significant (cf. 5.3.3).

What about the negative relation between monism and force-driven religious conflict against this background? Why would Hindu students be more inclined to attribute interreligious conflict to force-driven causes when they reject absolute truth claims, while we do not find this (negative) correlation among Christians and Muslims? The key to this question can be the Hindu conception of absolute truth, which differs from that of Christianity and Islam. According to Weber (1996) monotheistic religions formulate the concept of absolute truth in relation to their claim to universalism, which is primarily a claim to dogmatic truth. In Hinduism the idea of absolute truth is formulated in relation to the claim to a fixed set of rituals associated with a societal order (particularly the caste system). This connects the truth question in Hinduism with social order, influenced by the belief found in the Hindu myth of the great sacrifice of Purusha and the metaphysical doctrines of dharma, karma (doctrine of ethical compensation) and samsara (belief in transmigration of souls) (Shrirama 2007; Omvedt 2003). Rejection of absolute truth by Hindu students might imply a critical stance towards societal order and dismissing monism would entail approval of the use of coercive force to change society. The belief that societal change is possible - associated with rejection of monism - increases the likelihood that conflicts in society are indeed attributed to forcedriven economic, political or socio-cultural causes. We are not sure if the rejection of absolute truth claims has an impact on the attribution of specific conflicts between religious groups. Neither do we know whether interreligious conflicts are interpreted against the background of social conflict generally. But our interpretation is supported by socio-cultural and socio-economic personal characteristics, which correlate negatively with monism but positively with force-driven religious conflict. Hindu men (compared to women) and respondents whose fathers and mothers have lower educational levels agree more with monism (cf. Table 5.5), but less with force-driven religious conflict (cf. Table 7.3). Compared with men, women's position is more restricted by the 
order of society, and parental educational level is an important indicator of less opportunity to break free from the social order. To summarize our argument: for Hindu students disagreement with monism implies rejection of the order of society, entailing a likelihood that conflict is interpreted as a means of breaking free from that order.

\section{Commonality Pluralism}

A second unexpected finding is the (positive) effect of commonality pluralism on force-driven religious conflict among Muslim students only. How can agreement with commonality pluralism predict agreement with the attribution of conflict to force-driven causes?

An explanation may be found in Islamic theology and the minority position of Muslims in India. Communality pluralism accepts that different aspects of the same ultimate truth are revealed in different religions. Similarities between religions are building blocks to construct a universal religion, and all religions offer an equally profound experience of divine reality. Commonality pluralism puts Islam on the same level of truth as other religions, as opposed to the dominant idea in Islamic theology that the word of God revealed to Mohammad in the Qur'an is the fulfilment of all other revelations. In the regime of truth of Islamic theology stressing sameness between religions is a source of conflict with other religious groups (Arkoun 2002, 306). This may represent the particular experience of Tamil Muslims, who have had deep roots in Tamil country ever since the fourteenth century. The characterization of Tamil Muslims of the early period as 'half Hindu' by Amir Khusru, the court poet of Alauddin Khilji, seems to persist to this day. "Many Tamil Muslims complain even today that the Urdu-speaking Muslims of north Indian origin do not consider them as being on par and dismiss them very much in the manner of Amir Khusru" (More 2004, 11). Commonality seems to undermine the Muslim identity of Tamil Muslims in the Islamic world. This was also evident in Tamil Muslims' participation in the Self-Respect Movement founded by Ramasamy in 1925. Although it offered scope for intimate relations between non-Brahmin Hindus and Tamil Muslims, it created a problem of identity demarcation among the latter. "When these frontiers, which safeguarded the identity of the Tamil Muslims, were undermined by certain postures of the non-Brahmin Hindus, especially towards and after independence, the Tamil Muslims naturally reacted to assert their separate identity and to remind the non-Muslims of the frontiers that existed between them and the others" (More 2004, 197). 


\section{Religiocentrism: Positive In-group Attitudes}

How can we interpret the remarkable and divergent effects of religiocentrism on attitudes towards force-driven religious conflict? First we describe the possible mechanisms that explain how positive in-group attitudes reduce agreement with force-driven religious conflict. Then we discuss how negative out-group attitudes among Hindus can induce force-driven religious conflict.

How do we explain the negative relation between positive in-group attitudes and force-driven religious conflict? We found that Christian and Hindu students with low levels of positive in-group attitudes are more inclined to attribute interreligious conflict to force-driven causes. Conversely, stronger positive in-group attitudes reduce acceptance of force-driven religious conflict. Two different mechanisms may explain this negative correlation: self-esteem and religious involvement.

(a) With regard to self-esteem, we can say the following. In line with social identity theory, we described positive attitudes towards the in-group as intrinsically part of people's identity construction. People strive for a positive selfconcept and may achieve it by asserting their distinctness from others. They construct a positive self-image by identifying with positive in-group characteristics and contra-identifying with negative characteristics of both in-group and out-groups (Tajfel \& Turner 1979; cf. 6.2). For some scholars in-group bias in general and positive in-group attitudes in particular relate directly to self-esteem. This relation works in two directions: successful intergroup discrimination elevates self-esteem and threatened self-esteem promotes intergroup discrimination. In this interpretation relatively low levels of positive in-group attitudes are seen as an indicator of threatened or eroded self-esteem (Epstein 1990; Hogg \& Abrams 1990; cf. Rubin \& Hewstone 1998 for a detailed discussion of this contested self-esteem hypothesis). Threatened or eroded self-esteem leads to conflict, especially when there is competition for scarce material or immaterial resources. Conversely, conflict is a means to boost low self-esteem. According to Sidel (2007) self-identity is redefined in contexts of heightened states of anxiety. Through conflict people force others to take them into account or try to command respect. If low self-esteem relates to conflictive relations with others, it follows that people with low levels of positive in-group attitudes are readily inclined to attribute interreligious conflicts to coercive force in intergroup relations. Insofar as low self-esteem is accompanied by feelings of shame the out-group might be blamed for the low self-esteem, adding to out-group derogation. People are ashamed to belong to a group which has fewer positive characteristics than they had hoped for. According to Tangney and Dearing $(2004,60)$ "feelings of shame engender low self-esteem and, in turn, low self-esteem results in a vulnerability to feelings of shame". Shame can 
produce other-directed anger, because aggression tries to externalize the shame by blaming others. Violent actions serve to neutralize the feelings of shame. One can also formulate this from the perspective of symbolic interactionism. A core idea in symbolic interactionism is that self-awareness implies constant monitoring of the self from the point of view of others. We live in the minds of others', but this intersubjective bond with others is virtually indiscernible in modern society. It is manifested, however, in powerful social emotions that result from this awareness of 'living in the minds of others', namely pride and shame (Scheff 2005). Shame, and its weaker form embarrassment, are the result of unfulfilled expectations in interaction (Gardner \& Gronfein 2005, 176). The ideal self that I have in mind is not confirmed by my interaction with others. Violence deals with the shame that is the result of disconfirmation of my ideal self.

(b) However, we should stress that relating positive in-group attitudes to self-esteem, let alone identifying them, is heavily contested. A direct relation between positive in-group attitudes and self-esteem is regularly depicted as conflicting with the tenets of social identity theory, because it fails to distinguish between social and personal identity. After all, self-esteem refers to the overall evaluation of an individual person's worth. It is a personal judgment of one's personal worth based on self-perceived competence and the emotions attached to it (Zeigler-Hill 2013). In short, the self-esteem hypothesis too hastily leaps from social to personal identity issues, thus overlooking the 'social' strategies to maintain a positive self-concept like social mobility and social creativity (Long \& Spears 1997; Turner \& Oakes 1997; Rubin \& Hewstone 1998; Turner \& Reynolds 2003). Religious involvement might therefore be a more straightforward explanation of the negative relation between positive in-group attitudes and force-driven religious conflict. Maybe it is simply that positive in-group attitudes are an indicator of religious involvement with and commitment to one's own religious tradition, without including negative evaluation of others. Religiously involved and committed members of a religious tradition might find it difficult to recognize the close connection between religiosity and conflict.

\section{Religiocentrism: Negative Out-group Attitudes}

We also found some support for our seventh hypothesis: negative out-group attitudes induce attribution of interreligious conflict to force-driven causes. But we found this only among Hindu students, and then only in the case of negative attitudes towards Christians (not with regard to their negative attitudes towards Muslims). Why just Christians and not also Muslims? A possible explanation may lie in the differential amount of contact between our Hindu 
student respondents and members of the two minority groups. Our sample comprises a relative large proportion of Hindu students in Christian colleges, so one can reasonably expect them to have more contact with Christians than with Muslims, which makes their attitudes towards Christians more relevant in their daily life. Furthermore, ethnic competition theory explains why people are more negative towards others with whom they have more contact. The core idea in this theory is that actual or perceived "competition between ethnic groups, at an individual as well as a contextual level, may reinforce the mechanisms of social (contra)identification, the eventual outcome of which is referred to as ethnic exclusionism" (Scheepers et al. 2002, 18). Higher education can be seen as a competitive environment where some succeed and others fail and where students compete with each other to get the best starting position in the job market. Students working in a competitive context might find it easier to attribute interreligious conflict to economic, political, socio-cultural and religious rivalry. This is certainly the case when Hindu students have to do with Christian fellow students, who - in a Christian higher educational context probably have relatively high status. Further clarification is provided by intergroup contact theory. According to this theory more contact only leads to less out-group derogation under optimal conditions such as contact on an equal footing; common goals pursued by all parties involved; intergroup cooperation; and institutional support of cooperation from authorities, laws, norms, customs, et cetera. These are the classic conditions set by Allport $(1954,281)$ for intergroup contact to reduce out-group negativity. It is questionable whether these conditions are met in the case of our Hindu students. If not, it implies that experiences may also hinder the development of solidarity with out-group members, especially when strong in-group identification leads to exclusionary behaviour (cf. Pettigrew \& Tropp 2006; Hooghe et al. 2009).

\section{Mother's Educational Level}

Finally we found a direct influence of the mother's educational level on attitudes towards force-driven religious conflict among all religious groups. For Christian and Muslim students the mother's educational level is actually the strongest predictor of agreement with force-driven religious conflict. In India the mother's educational level is generally considered a good indicator of the family's socio-economic position. Low participation of women in higher education is problematic in India. The literacy rate in 2001 was $64 \%$, but even though the gap is narrowing, there is still a significant difference between female $(54 \%)$ and male $(75 \%)$ literacy. Only $1 \%$ of women attend university or college, versus $3 \%$ of men (Departments of School Education, Literacy and Higher Education 2007). Taking the mother's educational level as a socio- 
economic characteristic, high socio-economic status induces agreement with force-driven religious conflict. Mother's educational level also indirectly strengthens agreement with force-driven religious conflict through positive ingroup attitudes. For Christian students a more highly educated mother correlates with lower positive in-group attitudes, ${ }^{5}$ which in its turn leads to greater agreement with force-driven religious conflict.

In short, respondents from the upper socio-economic strata show significantly more agreement with force-driven religious conflict. Among the potential causes of interreligious conflict identified in our measurement are economic and political causes: economic causes like overt or tacit approval of violence as a means of social change, and political causes like political leaders' intervention in religious matters. In other words, wealth or power are perceived as reasons for conflict between religious groups among the upper socioeconomic strata. Apparently they readily visualize a relation between competition for material or immaterial resources on the one hand and interreligious conflict on the other.

This finding leads to a completely different topic: the role of beliefs in what is generally called the relation between the spiritual and material world. Which beliefs in the religious meaning system influence, mediate or moderate the possession of (material and non-material) resources? Which beliefs about possession may reduce religious conflict? And which of these beliefs exacerbate religious conflict? Which beliefs lead to solidarity and which beliefs fuel discord? Reflections on justice in terms of mercy, righteousness or salvation (found in all religious traditions), the concept of compassion in Christianity (Lk 6:20-21), zakat in Islam (Qur'an 30:39) and charity in Hinduism (Bhagavad Gita 10:05) are examples of beliefs about possession that can reduce religious conflict. But needless to say, religious beliefs about possession may also stimulate religious conflicts, for example when society, including the distribution of wealth and opportunities, is seen as God-given and therefore unchangeable.

5 For all religious groups higher parental educational levels of the parents correlate with more positive in-group attitudes: for Christian and Muslim students via the mother's education, for Hindu respondents via the father's. 